\title{
THE DEFINITION OF DIGITAL SHADOW ECONOMY
}

\author{
Rita REMEIKIENE ${ }^{a}$, Ligita GASPARENIENE ${ }^{\mathrm{b}}$, Friedrich Georg SCHNEIDER ${ }^{\mathrm{c}}$ \\ ${ }^{a, b}$ Economics Institute, Economics and Finance Management Faculty, \\ Mykolas Romeris University, Ateities g. 20, LT-08303, Vilnius, Lithuania \\ ${ }^{c}$ Department of Economics, Institute of Economic Policy, \\ Johannes Kepler University of Linz, A-4040 Linz-Auhof, Austria,
}

Received 05 November 2015; accepted 26 November 2016

\begin{abstract}
Considering the lack of the scientific studies on the selected topic, the authors of this article raise the aim to set up the definition of digital shadow economy and identify its distinctive features and channels. Thus far, the studies on illegal digital activities have covered ambiguous interpretations of digital shadow economy that incorporated both criminal and economic aspects of the activities performed. The results of the empirical research have enabled to formulate the definition of digital shadow economy that refers to illegal activities, such as digital service provision and sales of goods/services online, when operating exceptionally in digital space, the entities violate the existent legal norms and regulations with a pursuit of illegal mutual interest and material benefits. The newly formulated definition of digital shadow economy has served as a corner-stone for identification of the distinctive features and channels of this phenomenon. Hence, the results of the research may make a significant and weighty contribution to the development of the theory of economics and may raise the awareness of what the phenomenon of digital shadow economy implies.
\end{abstract}

Keywords: shadow economy, digital shadow economy, features of digital shadow economy, channels of digital shadow economy.

JEL Classification: E26.

\section{Introduction}

Although IT advances alongside with the spread of the Internet introduced innovative ways of business conduct, they also gave birth to "a new particular brand of entrepreneurs working at the limits of legality or plainly outside any legal frameworks" (Dobson et al. 2015: 179), thus providing an avenue for the wide scale of digital shadow activities. According to Holz et al. (2012), growing scopes of e-activities have stimulated dishonest financial gains from digital businesses, which, in turn, has led to the steep rise of digital shadow economy. Soaring scopes of illegal digital activities have been confirmed by various economic analy-

Corresponding author Rita Remeikiene

E-mail: rita.remeikiene@mruni.eu 
sis institutions, for instance, the Government Accountability Office (GAO), which, with reference to Bossler and Holt (2012), made the calculations showing that various forms of cybercrime cost the economy approximately $\$ 117.5$ billion each year (GAO 2007; Bossler, Holt 2012).

In addition to the lack of the official statistics, the difficulties posed by digital shadow economy include vagueness of the definition of this phenomenon. Thus far, the studies on illegal digital activities have covered the analysis of their solitary forms or manifestations, basically cybercrimes (Yip et al. 2012; Holz et al. 2012; Bossler, Holt 2012), e-fraud (Mello 2013; Vlachos et al. 2011; Amasiatu, Shah 2014 and others) and digital piracy (Sirkeci, Magnusdottir 2011; Camarero et al. 2014; Taylor 2012; Arli et al. 2015; Yu et al. 2015 and others). However, the phenomenon of digital shadow economy has never been researched as an entirety, nor its concept has been precisely defined either in national or in international levels. Scientific literature proposes a wide variety of interpretations of digital shadow (underground) economy. Nevertheless, such illegal online activities as cybercrimes, digital piracy or e-fraud essentially refer to criminal offenses, which should be separated from the definition of digital shadow economy considering the disparities of their nature. A precise definition of digital shadow economy as well as identification of its features and channels would provide a clear view of what this phenomenon refers to, and would contribute to improvement of the methodologies of shadow economy estimation. Considering the reasons explicated above, this article is aimed at formulation of the definition of digital shadow economy and identification of its features and channels. For the fulfilment of the defined aim, the following objectives have been raised: 1) to analyse the theoretical literature on available interpretations, features and channels of the phenomenon of digital shadow economy; 2) to select and present the methodology of the research; 3) to discuss which definitions, features and channels of digital shadow economy are considered most appropriate by the experts, and set up a definition of digital shadow economy. The methods of the research include scientific literature analysis and expert evaluation.

\section{Concepts, features and channels of digital shadow economy: theoretical background}

The analysis of the available definitions of shadow economy has revealed that scientific literature (Hope 2001, 2012, 2014; Buehn, Schneider 2012a; 2012b; Ponsaers et al. 2008; Herwartz et al. 2013; Dell' Anno, Solomon 2008) covers a wide variety of interpretations and constructs that are employed to explain this phenomenon. In fact, particular definitions and constructs depend on a purpose and an object of a scientific study, i.e. if scientists analyse illegal activities related to drug trafficking, prostitution, etc., they are inclined to use such terms as "black labour" or "underground economy"; if a purpose of a study is to estimate which share of taxes is evaded by entrepreneurs, the terms of "shadow economy", "unofficial economy" or "non-observed economy" are employed. It must be noted that the terms of "shadow economy" and "non-observed economy" are the most widely used in this context (Startiené, Trimonis 2009). The motives to act in a "shadow" depend on the balance between costs and benefits: in this sense, costs are borne if a "shadow" activity has 
been detected and a person has been punished, while benefits are obtained from evasion of taxes and/or social insurance contributions.

As it was admitted by Kenyan government to the International Labour Organisation (1972), activities in the informal sector of economics serve as an efficient measure of income distribution in the poorest segment of population (Woodward et al. 2011). At the same time, the other authors (Putniņš, Sauka 2011) argue that shadow economy covers all legal products and services, which are hidden from public authorities. Buehn and Schneider (2012b) state that shadow economy is an immeasurable economic phenomenon, and, to date, economists cannot agree on its precise definition. According to Herwartz et al. (2013), shadow economy refers to the aggregate of legal and illegal economic activities that should be included in GDP estimations, but are not registered by public authorities.

Shadow economy comprises of economic activities, enterprises and workers (both professionals and non-professionals), when the latter get involved into economic-commercial operations beyond the limits of legal economics, and such operations are not regulated or protected by a state (Hope 2014). Shadow economy covers all unregistered trade, finance and service provision activities as well as all forms of work without employment contracts and/or without payment of social insurance contributions and employee taxes in non-observed business.

With reference to Hope (2014), shadow economy should be referred to as: 1) non-observed employment in "shadow" business enterprises with employers, employees, self-employed people and unpaid family members; 2) non-observed employment in unofficially operating enterprises with local workers, random or daily workers, temporary or parttime workers, industrial homeworkers and other undeclared workers; 3) unregistered and non-observed small-scale financial/saving/deposit activities.

Despite the fact that the traditional definition of non-observed economy covers the above-mentioned activities and people, who operate in the underground sector, a new and expanded interpretation also considers all the types of paid work (i.e. whether a person works as a self-employed or as a hired employee), which is not observed, regulated or protected in the active legal framework of a state. This new interpretation substantiates an important conceptual shift and introduces a new attitude, which defines / recognizes an official informality in terms of an employment status, while traditional definitions are mostly based on the priorities to characteristics of an enterprise.

A detailed structure of shadow economy was proposed by Schneider and Enste (2002) (see Table 1). As it can be seen in Table 1, tax violations, illegal employment and abuse of social benefits make the basis of shadow economy, while drug trafficking, trade in stolen goods, forbidden gambling, smuggling, etc. are attributed to the criminal sector of economics. Work at home, childcare, self-help organisations, advisory centres and network activities compose the informal sector of economics. In one of their studies, Schneider et al. (2010: 444) employ the following definition of shadow economy: "shadow economy covers all goods and services in the market, where they are consciously hidden from public authorities in order to evade income taxes, VAT or social insurance contributions while striving to meet particular legal labour market standards, such as assurance of minimal wages, maximum of work hours, safety standards, etc., and complying with particular ad- 
ministrative procedures, such as filling statistical questionnaires or administrative forms". Petersen and Thießen (2010) interpret shadow economy as activities, which are related to tax evasion and transfer frauds.

According to Bossler and Holt (2012), a significant share of shadow economy revenue is generated in digital space. However, without a clear definition of digital shadow economy, its precise scopes cannot be estimated since it still remains vague which illegal (non-observed) digital activities should be considered as digital shadow economy generators and included in the estimations, and which of them should be left for criminal consideration.

Table 1. Classification of shadow economy

\begin{tabular}{|c|c|c|c|c|}
\hline \multirow{2}{*}{ Criteria } & \multicolumn{4}{|c|}{ Sectors } \\
\hline & Household & Informal & „Underground“ & Criminal \\
\hline $\begin{array}{l}\text { Production/ } \\
\text { Distribution }\end{array}$ & legal & legal & illegal & illegal \\
\hline $\begin{array}{l}\text { Transfers in } \\
\text { the market }\end{array}$ & no transfers & are conducted & are conducted & are conducted \\
\hline $\begin{array}{l}\text { Result (products/ } \\
\text { services) }\end{array}$ & legal & legal & legal & illegal \\
\hline Example & $\begin{array}{l}\text { To do } \\
\text { everything } \\
\text { by oneself; an } \\
\text { office at home; } \\
\text { barter; child } \\
\text { care }\end{array}$ & $\begin{array}{l}\text { Neighbours' } \\
\text { assistance; advisory } \\
\text { centres; self-help } \\
\text { organisations; } \\
\text { honorary activities; } \\
\text { network activities }\end{array}$ & $\begin{array}{l}\text { Illegal work: } \\
\text { violations of the } \\
\text { regulations on trade, } \\
\text { craft, distribution; } \\
\text { tax evasion; abuse of } \\
\text { social benefits }\end{array}$ & $\begin{array}{l}\text { Trade in stolen } \\
\text { goods and } \\
\text { drugs; forbidden } \\
\text { gambling; fraud; } \\
\text { smuggling; hiding } \\
\text { of stolen goods }\end{array}$ \\
\hline Categories & $\begin{array}{l}\text { Self-sufficient } \\
\text { economy }\end{array}$ & & Shadow economy & \\
\hline
\end{tabular}

Source: Schneider and Enste (2002: 11)

With reference to Holz et al. (2012), volatility as well as rapid advance of technologies make tracking and understanding of the phenomenon of digital shadow economy rather complicated. For this reason, scientific literature is rich in the variety of different interpretations of digital shadow economy, in accordance with the nature, general purpose or the subjects involved in the analysed phenomenon.

In the broad sense, the term of "digital shadow economy" is frequently aligned with the terms of "digital underground economy" and "digital black market", respectively meaning profit-driven Internet-based unregistered activities (Herley, Florencio 2010) and illegal revenues generated as a result of online trade and service provision (Zorz 2015). The latter interpretation resembles the definition proposed by Moore et al. (2009), according to whom digital underground economy refers to hidden profit driven online trading. The dictionary for investors in the website "Investopedia" describes digital black economy as a segment of a country's economic activity that is derived from the sources falling outside the country's rules and regulations regarding e-commerce. It is noted that digital black economies typically emerge as a result of restriction of economic activities either by making a transaction illegal or by taxing an item so much that it becomes cost-prohibitive. Thus, likewise tradi- 
tional shadow economies, digital shadow economies are presumed to make illegal goods and services available to potential purchasers or to make expensive items available for less money (for instance, pirated software) (Investopedia dictionary 2015).

Considering the illegal nature of digital shadow economy, its concept is closely related to the concept of cybercrime, which is interpreted as Internet-based crime, conducted remotely to illegally take wealth or resources from others (Smith 2015). Also, cybercrimes are referred to as offences committed by exploiting networked technology in order to carry out complex and far-reaching tasks that can be repeated countless times globally (Yip et al. 2012), robust underground economies that are industrialized by making and delivering the tools for criminal behaviour (Mello 2013) or technologically advanced criminal activities that cause serious threats for consumers, organizations and enterprises as well as for the public sector (e.g. utilization of bonnets, targeted attacks or custom malware) (Vlachos et al. 2011). Amasiatu and Shah (2014) invoke the term "faceless crimes", which is explained as fraudulent activities performed engaging IT and the Internet network for illegal business conduct, basically in retail industry.

It should be noted that the concept of digital shadow economy in the scientific literature goes beyond the illegal activities of online traders and service providers. It also involves product or service consumers (customers, purchasers) as the active participating subjects. Consumers' illegal activities online are often aligned with the terms of "e-piracy" and "e-fraud". E-piracy (or digital piracy) is defined as the illegal or unauthorized copying/ downloading of particular copyrighted content (Castro et al. 2009; Cronan, Al-Rafee 2008; Camarero et al. 2014). The related literature (Jacobs et al. 2001; Ho, Weinberg 2011) employs the terms of counterfeiting, product theft or bootlegging to refer to the general cases of product piracy. The central premise in e-piracy is benefit at the expense of the rightful owners of the authentic products/brands. In legal terms, it is an infringement of intellectual property rights (Camarero et al. 2014), causing deprivation of the legal owner of potential revenues and cash flows. With reference to Ho and Weinberg (2011), currently prevailing types of e-piracy include downloading of movies and other easily digitized entertainment products, downloading of softcopies and obtaining of hard copies of pirated products.

The term of "e-fraud" is basically linked to the breach of the contract established online (Hjort, Lantz 2012) or the breach of the trust between the contract parties (Amasiatu, Shah 2014). Having analysed the topic of e-fraud, Amasiatu and Shah (2014) note that in first party (consumer's) fraud, the trust is breached when a consumer reneges on the contract agreement. According to Vlachos et al. (2011), most of e-fraud cases are related to fraudulent transactions, as the users are seeking to purchase consumer goods (expensive clothes, computer and electronics equipment, music and entertainment devices) at discount prices.

Summarising, it can be stated that in its general sense, digital shadow economy refers to unregistered or illegal profit-driven activities in e-space, basically related to trade or service provision. However, it should be noted that such illegal profit-driven activities as cybercrimes, digital piracy or e-fraud are, in principle, criminal offenses. Thus, they should be separated from the definition of digital shadow economy and left for criminal consideration since the authors of the article are of the opinion that illegal economic and criminal activities have to be detached. Considering the interpretations of digital shadow economy 
available in the scientific literature, the following definition of the analysed phenomenon can be proposed:

- Digital shadow economy is a part of shadow economy, when illegal profit-driven online trade or service provision is performed. The activities of digital shadow economy have the trend to be of repeated or non-repeated nature with or without changing IP addresses/computer networks.

- Digital shadow economy refers to global networks emerging in closed Internet forums and promoting chains of e-crimes, including bank attacks, payment card crimes, identity steals and other Internet intrusions.

- (Un)interrupted, financial-gain-driven provision of particular commodities or services in the remote space, performed without activity registration and causing damage to an officially registered subject, who provides similar commodities or services.

- Digital shadow economy is an illegal operation in the Internet space, which generates illegal money flows for commodity/service providers or purchasers, and deprives legal traders/service providers from the revenue that could be officially accounted, calculated and declared.

- Digital shadow economy refers to the trade in e-space, performed without paying any taxes to the state budget, excluding purely criminal activities such as drug trafficking, prostitution, etc.

The analysis of the literature has also enabled to identify the theoretical features of digital shadow economy (see Table 2).

First of all, traders and service providers (physical or juridical entities) are considered to be the most active participating subjects (Zorz 2015; Moore et al. 2009; Vlachos et al. 2011), etc.) of digital shadow economy, although Herley and Florencio (2010) indicate that the nature of this activity may exceed the capacity of a closed group (i.e. an enterprise), which proposes that the subjects of digital shadow economy may also involve multinational enterprises (MNEs) or business networks. Emphasis that digital shadow economy activities are profit-driven reveals the general purpose of the phenomenon - financial gain (Holz

Table 2. Theoretical features of digital shadow economy

\begin{tabular}{ll}
\hline \multicolumn{1}{c}{ Nature } & \multicolumn{1}{c}{ Specification } \\
\hline Subjects & $\begin{array}{l}\text { Traders, service providers, consumers (purchasers); physical and juridical } \\
\text { entities, multinational enterprises (MNEs), business networks }\end{array}$ \\
\hline Forms & E-business, trade, service provision, cybercrime, e-piracy, e-fraud \\
\hline Purpose & Financial gain - profit, revenues, cash flows \\
\hline Registry & Unregistered, illegal \\
\hline Repeatability & Repeated, non-repeated \\
\hline Equipment & Sophisticated, advanced technologies \\
\hline Participant skills & Advanced, high level of coordination \\
\hline Detriment & $\begin{array}{l}\text { Deprivation of officially registered entities performing the similar types of ac- } \\
\text { tivities from potential gains (profit, revenues), lost revenues of the state budget }\end{array}$ \\
\hline Nature & Deceptive, non-deceptive \\
\hline
\end{tabular}


et al. 2012; Herley, Florencio 2010; Zorz 2015; Moore et al. 2009 and others). Inclusion of sophisticated equipment, the requirement for advanced technical skills as well as a high degree of coordination between the offending parties are also pointed out (Dittrich 2009; Provos et al. 2009; Vlachos et al. 2011). The basic detriment brought about by digital shadow economy is composed of deprivation of the officially registered entities from potential gains (profit, revenues) and lost revenues in the state budget (Vlachos et al. 2011; Holz et al. 2012; Dobson et al. 2015 and others). Finally, although some forms (e-fraud, cybercrimes) of digital shadow economy might reveal their deceptive nature, in particular cases (e-piracy) consumers, disposing information cues such as price, purchase location, materials used, etc., are fully aware of what they are acquiring, which opposes to them being deceived (Ho, Weinberg 2011). This leads to conclusion that voluntary nature of consumers may also determine a non-deceptive nature of digital shadow economy.

What concerns the channels of digital shadow economy, the analysis of the scientific literature has revealed that acting in digital space means exploitation of the remote space such as online shops, online service provision websites and social networks (Hafezieh et al. 2011; Levi, Williams 2013; Amasiatu, Shah 2014), e-advert and e-auction sites (Vlachos et al. 2011; Dion 2011; Smith 2015), cyber gambling and e-game portals (Vlachos et al. 2011; Smith 2015), online broadcasts (Dion 2011; Dobson et al. 2015), bitcoins and other cryptographic currencies (Haines, Johnstone 1999; Holz et al. 2012; Zorz 2015). With reference to Smith (2015), the channels of digital underground economy may include Internet access, computer hard drive space, financial resources, intellectual capital and other data or bandwidth. In other words, the resources of digital shadow economy contain the platforms that make users anonymous, allowing both clients and hosts to hide their geographical locations, which ensures that their activities and identities cannot be tracked (Zorz 2015).

\section{The methodology of the empirical research}

Although the structural part of shadow economy covered in this article tends to expand, the phenomenon of digital shadow economy has hardly been researched and constitutes a relatively new field of economic research. The analysis of the scientific literature has enabled to establish the basic features of digital shadow economy. However, it has also revealed significant differences in possible interpretations of the analysed phenomenon. In order to submit definition of digital shadow economy, the following objectives have been raised: 1) to formulate the definition of digital shadow economy; 2) to establish the features of digital shadow economy; 3) to identify the main resources of digital shadow economy.

The definition of digital shadow economy has been formulated with reference to the results of the qualitative expert evaluation. Since objectives 1-3 are aimed at revelation of the experts' attitudes towards the researched phenomenon, the method of questionnaire survey can be considered the most relevant data collection method for this research. Employment of the method of expert evaluation was also determined by the lack of the initial information on the researched topic.

The research based on this method, has to involve 10-100 experts, considering the primary purpose of the research as well as the competence of the experts in the researched 
field (Augustinaitis et al. 2009). The expert evaluation was carried out applying both direct (personal in-depth interviews) and indirect (telephone and e-mail interviews) methods of data collection on the basis of the questionnaire, which was prepared in advance. Apart from creativity, attitude towards the expertise, judgement flexibility, reliability, self-criticism and related qualities, scientific literature (Augustinaitis et al. 2009) emphasises the significance of expert competence. Thus, the selection of the experts was based on their competence, long-term experience, acknowledgment with the situation of shadow economy in Lithuania, and the most urgent problems caused by the researched phenomenon. Hereby, following the criteria mentioned above, the expert group for the survey involved 30 people: 22 Lithuanian experts, representing State Tax Inspectorate, the Government of the Republic of Lithuania, the Parliament of the Republic of Lithuania, Lithuanian Department of Statistics, the Bank of Lithuania, the Customs of Lithuania, the Lithuanian Chamber of Auditors and Lithuanian Free Market Institute, and 8 experts from foreign countries such as Latvia, Estonia, the United Kingdom and Austria.

At first, the experts were interviewed with a request to define digital shadow economy, identify its features and channels. The experts were presented the questions of the opened type, such as: "With reference to your experience, please describe, what digital shadow economy refers to" and "Please, point out the features and channels of digital shadow economy". In the second stage, the information was systematised. The questionnaire included several questions of the open type, where the experts were asked to write down their definitions, identify the features and channels of the researched phenomenon (see Appendix 1).

In their study, Augustinaitis et al. (2009) refer to Libby and Blashfield (1978), who proved that in the modules of aggregated expert evaluations with equal weights, the accuracy obtained while surveying small expert groups is not lower than the accuracy obtained while surveying large expert groups.

The lack of information about the phenomenon of digital shadow economy in Lithuania and all over the world determined the selection of in-depth interviews and expert evaluation as the most relevant methods for the empirical research. To date, the statistics on the scope of digital shadow economy has not been accumulated. According to the participants of the first survey, statistical data or mathematical estimations on the scope of digital shadow economy are not available without a clear definition of the phenomenon of digital shadow economy, and identification of its features and channels.

Analysis and interpretation of the research results. The questionnaire was composed of 2 structural parts: the first part was designed for accumulation of the general information about the experts (work experience, operation field/institution), while the second part helped to disclose experts' attitudes towards the proposed definitions, features and channels of digital shadow economy, and served as the basis for formulation of the final definition of digital shadow economy. The experts were asked to evaluate each of the statements in Likert evaluation scale, where rank 1 stands for the lowest (I completely disagree/it is completely insignificant), and rank 5 - for the highest possible evaluation (I completely agree/it is extremely significant). In accordance with the strength of agreement/disagreement with a particular statement, intermediate ranks 2,3 or 4 could be selected. 
The results of the research were processed with SSPS (Statistical Package for Social Sciences) and Microsoft Excel software. The generalized rank values have been presented in Table 3.

In Table 3, value $\mathrm{V}_{\text {jn }}$ reflects the level of significance, which was attributed to statement $n$ by expert $\mathrm{j}$. By employing the introduced matrix, rank sum $\mathbf{V}_{\mathbf{i}}$ for statement $i$ as well as rank sum $\mathbf{S}_{\mathbf{i}}$ average $\bar{s}$ for statement $i$ were estimated, and significance of each of the statements alongside with compatibility of the experts' opinions (expressed as Kendall's coefficient of concordance W) were established. Variability of Kendall's coefficient of concordance falls into the interval $0 \leq \mathrm{W} \leq 1$, which means that the values of the coefficient close to 1 show high compatibility of the experts' opinions. When $\mathrm{W} \leq 0.6$, compatibility of the expert evaluation results is considered weak, but if $\mathrm{p}<0.05$, the data can be treated as reliable.

Table 3. Matrix of the expert evaluation results on digital shadow economy concept, features and channels

\begin{tabular}{ccccccc}
\hline \multirow{2}{*}{ Experts } & \multicolumn{7}{c}{ Variables $(\mathrm{V})$} \\
\cline { 2 - 7 } & 1 & 2 & $\ldots$ & $\mathrm{i}$ & $\ldots$ & $\mathrm{N}$ \\
\hline 1 & $\mathrm{~V}_{11}$ & $\mathrm{~V}_{12}$ & $\ldots$ & $\mathrm{V}_{1 \mathrm{i}}$ & $\ldots$ & $\mathrm{V}_{1 \mathrm{n}}$ \\
\hline 2 & $\mathrm{~V}_{21}$ & $\mathrm{~V}_{22}$ & $\ldots$ & $\mathrm{V}_{2 \mathrm{i}}$ & $\ldots$ & $\mathrm{V}_{2 \mathrm{n}}$ \\
\hline$\ldots$ & $\ldots$ & $\ldots$ & $\ldots$ & $\ldots$ & $\ldots$ & $\ldots$ \\
\hline $\mathrm{J}$ & $\mathrm{V}_{\mathrm{j} 1}$ & $\mathrm{~V}_{\mathrm{j} 2}$ & $\ldots$ & $\mathrm{V}_{\mathrm{ji}}$ & $\ldots$ & $\mathrm{V}_{\mathrm{jn}}$ \\
\hline$\ldots$ & $\ldots$ & $\ldots$ & $\ldots$ & $\ldots$ & $\ldots$ & $\ldots$ \\
\hline $\mathrm{M}$ & $\mathrm{V}_{\mathrm{m} 1}$ & $\mathrm{~V}_{\mathrm{m} 2}$ & $\ldots$ & $\mathrm{V}_{\mathrm{mi}}$ & $\ldots$ & $\mathrm{V}_{\mathrm{mn}}$ \\
\hline
\end{tabular}

Rank sum

Kendall's coefficient of concordance, $\mathrm{W}$

p-value

Frequency of feature indication

When introducing the results of the expert evaluation, special attention should be drawn to interpretation of Cronbach alpha coefficient. Some scientists, e.g. Nunnally and Bernstein (1994), point out that Cronbach alpha coefficient must be higher than 0.7.

\section{The results of the empirical research on the definition, features and channels of digital shadow economy}

While processing the information on the competence and work experience of the experts involved in the survey, it has been estimated that 17 experts have acquired over fifteen-year experience in their occupation field; 5 experts have acquired one-to-four-year experience. A detailed distribution of the experts' work experience has been presented in Figure 1.

The researched involved 48 per cent of the experts representing State Tax Inspectorate (highest-level managers from various Lithuanian and Latvian regions), 15 per cent of the experts representing Department of Statistics, and 11 per cent of the experts representing 
the Lithuanian Chamber of Audit. Distribution of the experts' operation fields has been presented in Figure 2.

Cronbach alpha coefficient, calculated for the first subgroup of statements ("Concept of digital shadow economy") in the second part of the questionnaire ("Concept, features and channels of digital shadow economy"), was equal to 0.645 , which proposes that all the statements in the subgroup reflect the researched dimension with appropriate accuracy. With reference to the results of the scientific literature analysis, the following definitions of digital shadow economy were proposed for the experts' consideration and evaluation in Likert scale (see Table 4).

Average ranks that are equal or exceed 3.5 reveal more or less considerable experts' consent, while average ranks equal to 3.4 and lower show experts' dissent to the proposed

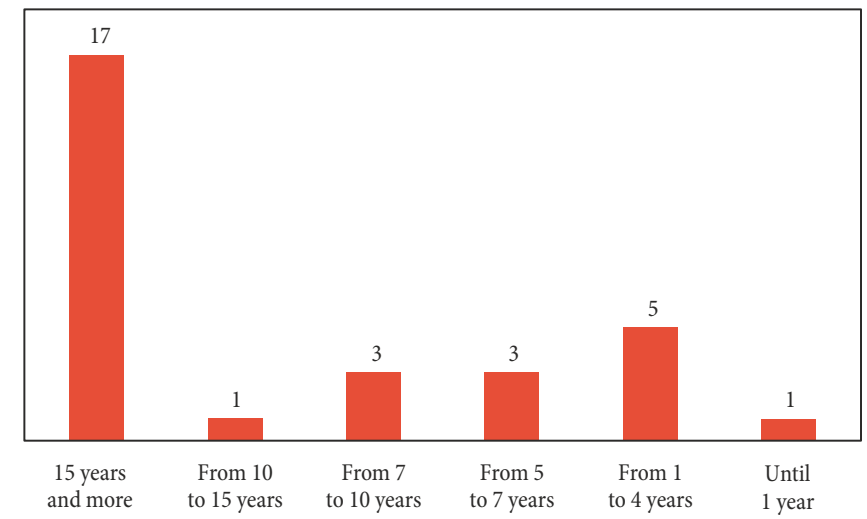

Fig. 1. Experts' work experience in current occupation field, frequency of answers (number)

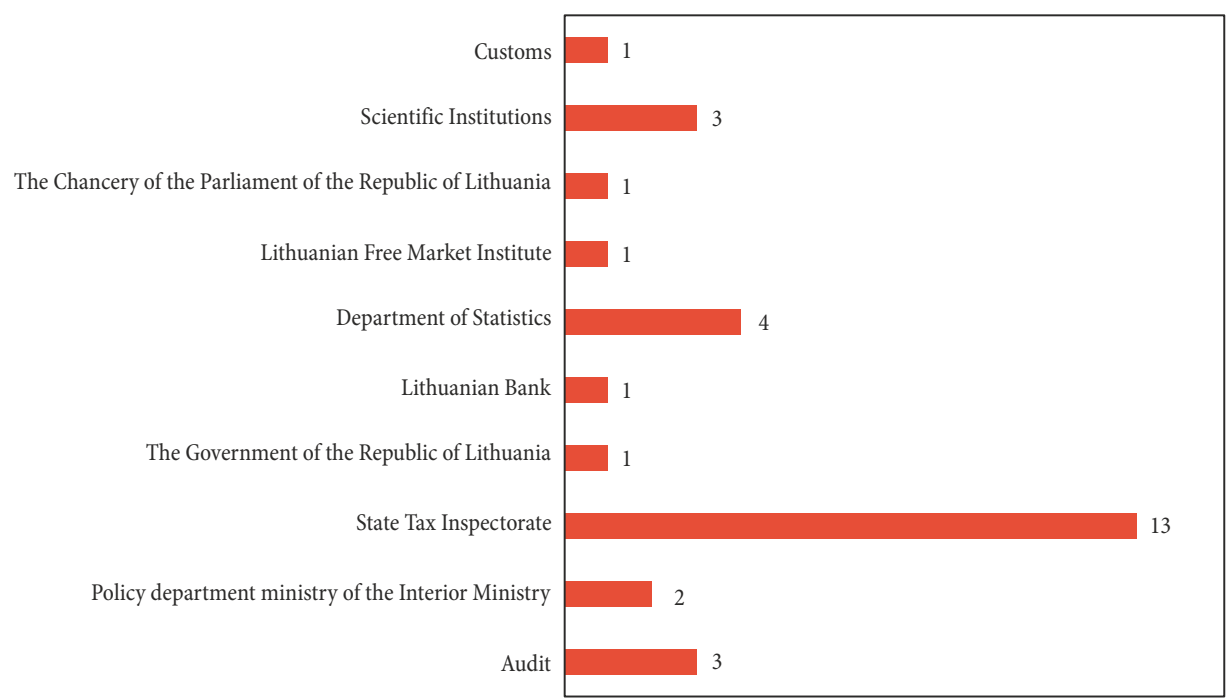

Fig. 2. Distribution of the experts by operation fields, in persons (number) 
definitions of digital shadow economy. Distribution of average ranks around numerical value 3, when Kendall's coefficient of concordance $\mathrm{W}^{\mathrm{a}}=0.207, \mathrm{p}=0.000$, disclosed that compatibility of the expert evaluations is comparatively weak, although reliable and statistically significant.

As it has been revealed by the data, introduced in Table 4, the highest average value (3.87) was estimated for the definition of digital shadow economy, proposing that digital shadow economy is an illegal operation in the Internet space, which generates illegal money flows for commodity/service providers or purchasers, and deprives legal traders/service providers from the revenue that could be officially accounted, calculated and declared. Slightly lower average value (3.77) was estimated for the definition implying that digital shadow economy refers to the trade in e-space, performed without paying any taxes to the state budget, excluding purely criminal activities such drug trafficking, prostitution, etc. The definition, proposing that (un)interrupted, financial-gain-driven provision of particular commodities or services in the remote space, performed without activity registration and causing damage to an officially registered subject, who provides similar commodities or services, scored the average rank of 3.7, i.e. it was slightly higher than the average rank of 3.63, which was estimated for the definition proposing that digital shadow economy is a part of shadow economy, when illegal profit-driven online trade or service provision is performed; the activities of digital shadow economy have the trend to be of repeated or non-repeated nature with or without changing IP addresses/computer networks.

The last definition of digital shadow economy, proposed for the expert evaluation (see Table 4), was found not to reflect the real nature of the researched phenomenon (average rank is equal to 2.53). In order to disclose the most explicit experts' attitudes towards digital

Table 4. Average ranks for acceptability of different concepts of digital shadow economy

\begin{tabular}{llc}
\hline No. & \multicolumn{1}{c}{ Proposed concepts of digital shadow economy } & Average rank \\
\hline & $\begin{array}{l}\text { Digital shadow economy is a part of shadow economy, when illegal profit- } \\
\text { driven online trade or service provision is performed. The activities of digital } \\
\text { shadow economy have the trend to be of repeated or non-repeated nature with } \\
\text { or without changing IP addresses/computer networks. }\end{array}$ & 3.63 \\
\hline $\begin{array}{l}\text { Digital shadow economy refers to global networks emerging in closed Internet } \\
\text { forums and promoting chains of e-crimes, including bank attacks, payment } \\
\text { card crimes, identity steals and other Internet intrusions. }\end{array}$ & 2.53 \\
\hline & $\begin{array}{l}\text { (Un)interrupted, financial gain driven provision of particular commodities } \\
\text { or services in the remote space, performed without activity registration } \\
\text { and causing damage to an officially registered subject, who provides similar } \\
\text { commodities or services. }\end{array}$ \\
\hline & $\begin{array}{l}\text { Digital shadow economy is an illegal operation in the Internet space, which } \\
\text { generates illegal money flows for commodity/service providers or purchasers, } \\
\text { and deprives legal traders/service providers from the revenue that could be } \\
\text { officially accounted, calculated and declared. }\end{array}$ \\
\hline & 3.70 \\
\hline $\begin{array}{l}\text { Digital shadow economy refers to the trade in e-space, performed without } \\
\text { paying any taxes to the state budget, excluding purely criminal activities such } \\
\text { as drug trafficking, prostitution, etc. }\end{array}$ & 3.77 \\
\hline
\end{tabular}


shadow economy, they were asked to formulate and propose the definition, which would reflect the nature of this phenomenon in the most accurate way. With reference to the expert representing State Tax Inspectorate, digital shadow economy covers the activities, performing which the entities neither account nor declare the income earned, or do not pay taxes to the budget of the state, where shadow activities are performed. According to the representative of the Government of the Republic of Lithuania, digital shadow economy refers to the processes in both regulated and unregulated economics, when these processes are performed by violating existent legal norms with a purpose to earn illegal material (economic, tax-related, financial) benefits and exceptionally exploiting digital/internet space.

With reference to the representative of Lithuanian Free Market Economy, digital shadow, first of all, should be defined considering two relatively distinct elements such as digital services (e.g., programming) and exploitation of the Internet as the operational platform (e.g., sales of material objects by the Internet). The basic criteria of digital shadow economy include illegality, i.e. service provision or sales executed by violating legal regulations, and mutual interest of transaction parties to participate in this business. Leaning on the opinions of the foreign experts, digital shadow economy refers to unregistered or/and undeclared as well as illegal activity that generates profit, and where digital measures like Internet services (or technologies) are used to perform that activity. Also, it is involvement in unregistered economic activities through the Internet services in order to escape payment of tax to authorities.

Thus, the results of the expert evaluation propose that while defining digital shadow economy, violation of legal regulations for economic purposes should be separated from crime commission, i.e. deterioration of assets and property rights, for instance, thefts, smuggling, offenses.

Summarising the results of the empirical research for the first subgroup of statements, titled "The concept of digital shadow economy", it can be stated that digital shadow economy represents illegal activities, which have to be separated from criminal actions, although both types of activities are performed violating existent legal norms and regulations. Digital shadow businesses are executed by exceptionally exploiting the Internet and e-space as the platforms for service provision or sales. While operating in digital environment, a pursuit for profit as well as voluntary participation emerge as the key criteria of digital shadow business, causing the damage to the state in the form of unaccounted, undeclared revenues and unpaid taxes.

With reference to the results of the expert evaluation, the authors of this article propose the following definition of digital shadow economy: Digital shadow economy refers to illegal activities, such as digital service provision and sales of goods/services online, when operating exceptionally in digital space, the entities violate the existent legal norms and regulations with a pursuit of illegal mutual interest and material benefits.

The features of digital shadow economy, proposed for the expert evaluation, were included in the questionnaire following the principle, analogical to the one applied while including the proposed definitions of digital shadow economy. Cronbach alpha coefficient equal to $\mathbf{0 . 9 4 3}$ shows that all questions in the scale reflect the target dimension with appropriate accuracy. The value of Kendall's coefficient of concordance $\mathrm{W}^{\mathrm{a}}=0.08$, and $\mathrm{p}=0.018$ 
reveal that the experts' answers are statistically significant, although their reliability is comparatively weak, i.e. while identifying the features of digital shadow economy, the experts' evaluations diverged. Divergence of the evaluations can be justified considering the fact that neither the definitions nor features of digital shadow economy thus far have been comprehensively defined in the scientific literature or legal acts. Due to this reason, the experts based their evaluations only on personal experience and perception. The results of the expert evaluation have been illustrated in Table 5.

Table 5. Average ranks for the features of digital shadow economy

\begin{tabular}{clc}
\hline No. & \multicolumn{1}{c}{ Features of digital shadow economy } & Average ranks \\
\hline 1. & Anonymity & 3.73 \\
\hline 2. & Illegal operations are performed exceptionally in electronic space & 3.60 \\
\hline & $\begin{array}{l}\text { Meager risk of prosecution for illegal activities in comparison to that in } \\
\text { traditional shadow economy, determined by the lack of appropriate control } \\
\text { measures }\end{array}$ & 3.59 \\
\hline 4. & Hardly defined and determined geographical location & 3.93 \\
\hline 5. & $\begin{array}{l}\text { Advanced participants' (intermediaries') IT knowledge and skills, fluent } \\
\text { English skills }\end{array}$ & 3.63 \\
\hline 6. & $\begin{array}{l}\text { Communication take place only in e-space, without having any physical } \\
\text { contact }\end{array}$ & 3.77 \\
\hline 7. & Higher speed of illegal transactions, available round-the-clock & 4.27 \\
\hline 8. & Engagement of e-payment: systems, e-accounts/currencies & 3.83 \\
\hline 9. & Positioning and advertising of goods/services exceptionally in the Internet & 3.87 \\
\hline
\end{tabular}

The results of the empirical research have disclosed that all the features of digital shadow economy, proposed for the expert evaluation (average ranks exceeded 3.5), can be attributed to digital shadow economy. Nevertheless, higher speed of illegal transactions, available round-the-clock, can be considered the most significant feature of digital shadow economy with its average rank of 4.27. The feature denoting hardly defined and determined geographical location of digital shadow economy (average rank 3.93) is ranked as second, while ones indicating positioning and advertising of goods/services exceptionally in the Internet (with average ranks equal to 3.87) are ranked as third by their significance.

Referring to the identified features of digital shadow economy, it can be stated that the speed of illegal transactions in digital shadow economy is much higher in comparison to the speed of transactions in traditional shadow economy; what is more, geographical location of transactions is hardly defined, and transactions themselves take place only in e-space, without participants having any physical contact. The other proposed features of digital shadow economy, such as employment of e-payment systems, e-accounts and e-currencies, anonymity, advanced participants' (intermediaries') IT knowledge, skills, and fluent English skills, earned lower average ranks, which leads to the conclusion that they may describe not only digital, but also traditional shadow economy. 
The features of digital shadow economy with the lowest average ranks (respectively equal to 3.60 and 3.59) cover performance of illegal operations exceptionally in electronic space and meager risk of prosecution. Due to the reason that thus far no precise definition of digital shadow economy has been introduced, the experts' attitudes towards the proposed features were at variance. The lack of efficient digital shadow economy control measures (an efficient management mechanism) may also be considered as caused by the indeterminacy of the definition and features of the researched phenomenon.

Cronbach alpha coefficient, estimated for the proposed channels of digital shadow economy, was equal to $\mathbf{0 . 7 1 2}$, which indicates that all questions in the scale reflect the researched dimension with appropriate accuracy. The value of Kendall's coefficient of concordance was $\mathrm{W}^{\mathrm{a}}=0.181$, and $\mathrm{p}=0.000$. The average ranks, estimated for the proposed channels of digital shadow economy, have been illustrated in Table 6 .

Table 6. Average ranks for the channels of digital shadow economy

\begin{tabular}{clc}
\hline No. & Channels of digital shadow economy exploited violating existent legal acts & Average ranks \\
\hline 1. & Online shops with e-payment systems & 3.97 \\
\hline 2. & Poker/casino/bingo suppliers' portals & 3.90 \\
\hline 3. & E-game portals & 3.77 \\
\hline 4. & E-services, e.g. e-advert & 3.67 \\
\hline 5. & Online broadcasts & 3.33 \\
\hline 6. & E-trade in social networks & 4.07 \\
\hline 7. & Payments in bitcoins and other cryptographic currencies & 3.93 \\
\hline 8. & E-advert sites & 4 \\
\hline
\end{tabular}

The data presented in Table 6 reveals that the basic channels of digital shadow economy include e-trade in social networks (average rank 4.07), e-adverts sites (average rank 3.97) and online shops with e-payment systems (average rank 4.0). Payments in bitcoins and other cryptographic currencies alongside with e-advert sites, both with average ranks equal to 3.93 , are ranked in second position by their significance. Potential channels of digital shadow economy, with reference to the experts, cover e-gambling (poker/casino/bingo) suppliers' portals (average rank 3.90) and e-game portals (average rank 3.77).

Summarising the results of the empirical research, the authors of the article form the following original conclusions:

Digital shadow economy refers to illegal activities, such as digital service provision and sales of goods/services online, when operating exceptionally in digital space, the entities violate the existent legal norms and regulations with a pursuit of illegal mutual interest and material benefits.

Distinctive features of digital shadow economy cover high speed of illegal transactions, available round-the-clock, hardly defined and determined geographical location of transactions, and communication only in e-space, without participants having any physical contact. The other features that might be attributed to both digital and traditional shadow economy include anonymity, engagement of e-payment systems, e-accounts/currencies, and advanced participants' (intermediaries') IT and English skills. 
The basic channels of digital shadow economy include online shops with e-payment systems, e-gambling (poker/casino/bingo) suppliers' portals, e-game portals, e-trade in social networks, payments in bitcoins and other cryptographic currencies, and e-advert sites.

\section{Conclusions}

The research has revealed that the phenomenon of digital shadow economy has never been studied as an entirety, nor its definition has been precisely formulated either in national or in international levels. The literature proposes a wide variety of interpretations of digital shadow (underground) economy, which, in general sense, refers to unregistered or illegal profit-driven activities in e-space, basically related to trade or service provision. Nevertheless, such illegal profit-driven activities as cybercrimes, digital piracy or e-fraud are, in principle, criminal offenses. Hence, they should be separated from the definition of digital shadow economy and left for criminal consideration.

The qualitative empirical research (the expert evaluation) has enabled to formulate the definition of digital shadow economy: digital shadow economy refers to illegal activities, such as digital service provision and sales of goods/services online, when operating exceptionally in digital space, the entities violate the existent legal norms and regulations with a pursuit of illegal mutual interest and material benefits.

Ranking of the experts' evaluations has enabled to identify the distinctive features of digital shadow economy, which cover high speed of illegal transactions, available roundthe-clock, hardly defined and determined geographical location of transactions, and communication only in e-space, without participants having any physical contact. It has also revealed the basic channels of the analysed phenomenon, which include online shops with e-payment systems, e-gambling (poker/casino/bingo) suppliers' portals, e-game portals, e-trade in social networks, payments in bitcoins and other cryptographic currencies, and e-advert sites.

A precise definition of digital shadow economy as well as identification of its features and channels may not only provide a clear view of what this phenomenon refers to, but may also contribute to improvement of the methodologies of shadow economy estimation. Hence, the results of the research may make a significant and weighty contribution to the development of the theory of economics.

\section{Funding}

This work was supported by the Research Council of Lithuania [grant number MIP015/2015]. 


\section{References}

Augustinaitis, A.; Rudzkienè, V.; Petrauskas, R.; Dagytė, I.; Martinaitytė, E.; Leichteris, E.; Malinauskiene, E.; Višnevska, V.; Žilionienè, I. 2009. Lietuvos e. valdžios gairès: ateities įžvalgų tyrimas: kolektyvinè monografija. Vilnius: Mykolas Romeris University Publishing Centre.

Amasiatu, C. V.; Shah, M. H. 2014. First party fraud: a review of the forms and motives of fraudulent consumer behaviours in e-tailing, International Journal of Retail \& Distribution Management 42(9): 805-817. https://doi.org/10.1108/IJRDM-05-2013-0112

Arli, D.; Tjiptono, F.; Porto, R. 2015. The impact of moral equity, relativism and attitude on individuals' digital piracy behaviour in a developing country, Marketing Intelligence \& Planning 33(3): 348-365. https://doi.org/10.1108/MIP-09-2013-0149

Bossler, A. M.; Holt, T. J. 2012. Patrol officers' perceived role in responding to cybercrime, Policing an International Journal of Police Strategies \& Management: 35(1): 165-181. https://doi.org/10.1108/13639511211215504

Buehn, A.; Schneider, F. 2012a. Shadow economies around the world: novel insights, accepted knowledge, and new estimates, Int Tax Public Finance 19: 139-171. https://doi.org/10.1007/s10797-011-9187-7

Buehn, A.; Schneider, F. 2012b. Corruption and the shadow economy: like oil and vinegar, like water and fire?, Int Tax Public Finance 19: 172-194. https://doi.org/10.1007/s10797-011-9175-y

Camarero, C.; Anton, C.; Rodriguez, J. 2014. Technological and ethical antecedents of e-book piracy and price acceptance: evidence from the Spanish case, The Electronic Library 32(4): 542-566. https://doi.org/10.1108/EL-11-2012-0149

Castro, D.; Bennett, R.; Andes, S. 2009. Steal these policies: strategies for reducing digital piracy [online], [cited 17 October 2015]. The Information Technology and Information Foundation. Available from Internet: www.itif.org/publications/steal-these-policies-strategies-reducing-digital-piracy

Cronan, T. P.; Al-Rafee, S. 2008. Factors that influence the intention to pirate software and media, Journal of Business Ethics 78(4): 527-545. https://doi.org/10.1007/s10551-007-9366-8

Dell' Anno, R.; Solomon, O. H. 2008. Shadow economy and unemployment rate in USA: is there a structural relationship? An empirical analysis, Applied Economics 40(19): 2537-2555. https://doi.org/10.1080/00036840600970195

Dion, M. 2011. Corruption, fraud and cybercrime as dehumanizing phenomena, International Journal of Social Economics 38(5): 466-476. https://doi.org/10.1108/03068291111123156

Dittrich, D. 2009. Malware to crimeware: how far have they gone, and how do we catch up?, Login 34(4): 35-44.

Dobson, S.; Sukumar, A.; Tipi, L. 2015. Dark matters: the institutional entrepreneurship of illicit and illegal cyberspace, in G. Mcelwee, R. Smith (Eds). Contemporary Issues in Entrepreneurship Research, Volume 5: Exploring Criminal and Illegal Enterprise: New Perspectives on Research, Policy \& Practice. Emerald Group Publishing Limited, 179-201. http://doi.org/10.1108/S2040-724620150000005014

Government Accounting Office (GAO). 2007. Cybercrime: Public and Private Entities Face Challenges in Addressing Cyber Threats [online], [cited 10 October 2015]. United States Government Accountability Office Report to Congressional Requesters. Available from Internet: www.gao.gov/new.items/ d07705.pdf

Hafezieh, N., Akhavan, P.; Eshraghian, F. 2011. Exploration of process and competitive factors of entrepreneurship in digital space: a multiple case study in Iran, Education, Business and Society: Contemporary Middle Eastern Issues 4(4): 267-279. https://doi.org/10.1108/17537981111190051

Haines, J.; Johnstone, P. 1999. Global cybercrime: new toys for the money launderers, Journal of Money Laundering Control 2(4): 317-325. https://doi.org/10.1108/eb027198 
Herley, C.; Florencio, D. 2010. Nobody sells gold for the price of silver: dishonesty, uncertainty and the underground economy [online], [cited 10 October 2015]. Economics of Information Security and Privacy. Available from Internet: http://link.springer.com/chapter/10.1007\%2F978-1-4419-69675_3\#page-1

Herwartz, H.; Tafenau, E.; Schneider, F. 2013. One share fits all? Regional variations in the extent of the shadow economy in Europe. Regional Studies. (in press) https://doi.org/10.1080/00343404.2013.848034

Hjort, K.; Lantz, B. 2012. (R)e-tail borrowing of party dresses: an experimental study, International Journal of Retail \& Distribution Management 40(12): 997-1012. https://doi.org/10.1108/09590551211274964

Ho, J.; Weinberg, C. B. 2011. Segmenting consumers of pirated movies, Journal of Consumer Marketing 28(4): 252-260. https://doi.org/10.1108/07363761111143141

Hope, K. R. 2001. Indigenous small enterprise development in Africa: growth and impact of the subterranean economy, The European Journal of Development Research 13: 30-46. https://doi.org/10.1080/09578810108426779

Hope, K. R. 2012. The political economy of development in Kenya. New York, NY: Bloomsbury.

Hope, K. R. 2014. Informal economic activity in Kenya: benefits and drawbacks, African Geographical Review 33(1): 67-80. http://doi.org/10.1080/19376812.2013.838687

Holz, T.; Engelberth, M.; Freiling, F. 2012. Learning more about the underground economy: a casestudy of keyloggers and dropzones, ESORICS Proceedings 9: 1-18.

Investopedia dictionary. 2015. Definition of black economy [online], [cited 16 October 2015]. Available from Internet: http://www.investopedia.com/terms/b/black-economy.asp

Jacobs, L.; Samli, A. C.; Jedlik, T. 2001. The nightmare of international product piracy, Industrial Marketing Management 30(6): 499-509. https://doi.org/10.1016/S0019-8501(99)00105-4

Levi, M.; Williams, M. L. 2013. Multi-agency partnerships in cybercrime reduction, Information Management \& Computer Security 21(5): 420-443. https://doi.org/10.1108/IMCS-04-2013-0027

Libby, R.; Blashfield, R. K. 1978. Applications of item response theory to practical testing problems. Hillsdale, NJ: Erlbaum.

Mello, J. P. 2013. Cybercrime fueled by mature digital underground [online], [cited 10 October 2015]. Identity \& Access. Available from Internet: http://www.csoonline.com/article/2133649/identityaccess/cybercrime-fueled-by-mature-digital-underground.html

Moore, T.; Clayton, R.; Anderson, R. 2009. The economics of online crime, Journal of Economic Perspectives 23(3): 3-20. https://doi.org/10.1257/jep.23.3.3

Nunnally, J. C.; Bernstein, I. H. 1994. Psychometric theory. 3rd ed. New York: McGraw-Hill.

Petersen, H. G.; Thießen, U. 2010. Editor's introduction: shadow economy in high income countries much ado about nothing?, International Economic Journal 24(4): 413-419. https://doi.org/10.1080/10168737.2010.525970

Ponsaers, P.; Shapland, J.; Williams, C. C. 2008. Does the informal economy link to organized crime?, International Journal of Social Economics 35(9): 644-650. https://doi.org/10.1108/03068290810896262

Provos, N.; Rajab, M. A.; Mavrommatis, P. 2009. Cybercrime 2.0: when the cloud turns dark, Commun ACM 52(4): 42-7. https://doi.org/10.1145/1498765.1498782

Putniņš, T. J.; Sauka, A. 2011. Size and determinants of shadow economies in the Baltic States, Baltic Journal of Economics 11(2): 5-25. https://doi.org/10.1080/1406099X.2011.10840498

Schneider, F.; Enste, D. H. 2002. The Shadow Economy. An International Survey. Cambridge: Cambridge University Press.

Schneider, F.; Buehn, A.; Montenegro, C. 2010. New estimates for the shadow economies all over the world, International Economic Journal 24(4): 443-461. https://doi.org/10.1080/10168737.2010.525974 
Sirkeci, I.; Magnusdottir, L. B. 2011. Understanding illegal music downloading in the UK: a multi-attribute model, Journal of Research in Interactive Marketing 5(1): 90-110. https://doi.org/10.1108/17505931111121543

Smith, G. S. 2015. Management models for international cybercrime, Journal of Financial Crime 22(1): 104-125. https://doi.org/10.1108/JFC-09-2013-0051

Startienè, G.; Trimonis, K. 2009. Oficialiai neapskaitytos ekonomikos mastas, Economics \& Management 14: 976-983.

Taylor, S. A. 2012. Evaluating digital piracy intentions on behaviors, Journal of Services Marketing 26(7): 472-483. https://doi.org/10.1108/08876041211266404

Vlachos, V.; Minou, M.; Assimakopouos, V.; Toska, A. 2011. The landscape of cybercrime in Greece, Information Management \& Computer Security 19(2): 113-123. https://doi.org/10.1108/09685221111143051

Yip, M.; Shadbolt, N.; Tiropanis, N.; Webber, C. 2012. The digital underground economy: a social network approach to understanding cybercrime [online], [cited 09 October 2015]. Digital Futures 2012: The Third Annual Digital Economy All Hands Conference. Available from Internet: http://eprints.soton. ac.uk/343351/1/yip_de2012_submission.pdf

Yu, C. P.; Young, M. L.; Ju, B. C. 2015. Consumer software piracy in virtual communities: an integrative model of heroism and social exchange, Internet Research 25(2): 317-334. https://doi.org/10.1108/IntR-08-2013-0187

Zorz, M. 2015. Global black markets and the underground economy [online], [cited 12 October 2015]. Featured News. Available from Internet: http://www.net-security.org/article.php?id=2288

Woodward, D.; Rolfe, R.; Ligthelm, A.; Guimarães, P. 2011. The viability of informal microenterprise in South Africa, Journal of Developmental Entrepreneurship 16(1): 65-86.

https://doi.org/10.1142/S1084946711001719

\section{APPENDIX}

\section{Dear Expert,}

Thank you for your agreement to fill in this questionnaire.

Doc. Dr. Rita Remeikiene and Prof. Dr. Ligita Gaspareniene, Mykolas Romeris University, Faculty of Economics and Finance Management, Lithuania, are conducting the research on the topic "Digital shadow economy". One of the aims of the research is to analyse the phenomenon of shadow economy in respect of the usage of digital technologies for shadow activities online. The objectives of the research are to identify the forms, features of digital shadow economy. What is more, filling in this questionnaire, you will help to define the definition of digital shadow economy.

Your participation in the research is extremely important. At your request, we will introduce you with the research results.

Please, return the filled questionnaire at the e-mail: rita.remeikiene@mruni.eu 


\section{PART I. GENERAL INFORMATION ABOUT THE EXPERT}

1. Your experience in the current activity field:
a) from 1 to 4 years
b) from 5 to 7 years
c) from 7 to 10 years
d) from 10 to 15 years
e) over 15 years

2. Area /Institution where You work:
a) Audit
b) Customs
c) Police Department
d) Gambling Control Service
e) State Tax Inspectorate
f) The Chancery/Ministry of State's Government
g) The Service for Investigation of Financial Crimes
h) Central bank
j) Department of Statistics
g) Other (please, write down)

\section{PART II. CONCEPT AND FEATURES OF DIGITAL SHADOW ECONOMY}

3. Please, evaluate the importance of the below presented statements/definitions. For evaluations, follow a five-point scale: from 1 point - I strongly disagree with the statement; it describes "digital shadow economy" in the least accurate way to 5 points - I strongly agree with the statement; it describes "digital shadow economy" in the most accurate way. Different statements can be evaluated equally.

\begin{tabular}{|l|c|c|c|c|c|}
\hline \multicolumn{1}{|c|}{$\begin{array}{c}\text { PROPOSED CONCEPTS } \\
\text { of digital shadow economy }\end{array}$} & $\begin{array}{c}\text { Strongly } \\
\text { disagree }\end{array}$ & $\begin{array}{c}\text { Dis- } \\
\text { agree }\end{array}$ & $\begin{array}{c}\text { Neither agree } \\
\text { or disagree }\end{array}$ & Agree & $\begin{array}{c}\text { Strongly } \\
\text { agree }\end{array}$ \\
\hline $\begin{array}{l}\text { Digital shadow economy is a part of shadow } \\
\text { economy, when illegal profit-driven online } \\
\text { trade or service provision is performed. The } \\
\text { activities of digital shadow economy have the } \\
\text { trend to be of repeated or non-repeated nature } \\
\text { with or without changing IP addresses/com- } \\
\text { puter networks. }\end{array}$ & 1 & 2 & 3 & 4 & 5 \\
\hline $\begin{array}{l}\text { Digital shadow economy refers to global net- } \\
\text { works emerging in closed Internet forums and } \\
\text { promoting chains of e-crimes, including bank } \\
\text { attacks, payment card crimes, identity steals } \\
\text { and other Internet intrusions. }\end{array}$ & 1 & 2 & 3 & 4 & 5 \\
\hline
\end{tabular}




\begin{tabular}{|c|c|c|c|c|c|}
\hline $\begin{array}{l}\text { (Un)interrupted, financial gain driven provi- } \\
\text { sion of particular commodities or services in } \\
\text { the remote space, performed without activity } \\
\text { registration and causing damage to an offi- } \\
\text { cially registered subject, who provides similar } \\
\text { commodities or services. }\end{array}$ & 1 & 2 & 3 & 4 & 5 \\
\hline $\begin{array}{l}\text { Digital shadow economy is an illegal oper- } \\
\text { ation in the Internet space, which generates } \\
\text { illegal money flows for commodity/service } \\
\text { providers or purchasers, and deprives legal } \\
\text { traders/service providers from the revenue } \\
\text { that could be officially accounted, calculated } \\
\text { and declared. }\end{array}$ & 1 & 2 & 3 & 4 & 5 \\
\hline $\begin{array}{l}\text { Digital shadow economy refers to the trade in } \\
\text { e-space, performed without paying any taxes } \\
\text { to the state budget, excluding purely criminal } \\
\text { activities such as drug trafficking, prostitu- } \\
\text { tion, etc. }\end{array}$ & 1 & 2 & 3 & 4 & 5 \\
\hline $\begin{array}{l}\text { Please, write down your suggested concept of } \\
\text { digital shadow economy }\end{array}$ & & & & & \\
\hline
\end{tabular}

\section{Please, evaluate the features of digital shadow economy proposed below:}

\begin{tabular}{|l|c|c|c|c|c|}
\hline FEATURES of digital shadow economy & $\begin{array}{c}\text { Strongly } \\
\text { disagree }\end{array}$ & Disagree & $\begin{array}{c}\text { Neither agree } \\
\text { or disagree }\end{array}$ & Agree & $\begin{array}{c}\text { Strongly } \\
\text { agree }\end{array}$ \\
\hline Anonymity. & 1 & 2 & 3 & 4 & 5 \\
\hline $\begin{array}{l}\text { Illegal operations are performed } \\
\text { exceptionally in electronic space. }\end{array}$ & 1 & 2 & 3 & 4 & 5 \\
\hline $\begin{array}{l}\text { Meager risk of prosecution for illegal } \\
\text { activities in comparison to that in traditional } \\
\text { shadow economy, determined by the lack of } \\
\text { appropriate control measures. }\end{array}$ & 1 & 2 & 3 & 4 & 5 \\
\hline $\begin{array}{l}\text { Hardly defined and determined geographical } \\
\text { location . }\end{array}$ & 1 & 2 & 3 & 4 & 5 \\
\hline $\begin{array}{l}\text { Advanced participants' (intermediaries') IT } \\
\text { knowledge and skills, fluent English skills. }\end{array}$ & 1 & 2 & 3 & 4 & 5 \\
\hline $\begin{array}{l}\text { Communication take place only in e-space, } \\
\text { without having any physical contact. }\end{array}$ & 1 & 2 & 3 & 4 & 5 \\
\hline $\begin{array}{l}\text { Higher speed of illegal transactions, available } \\
\text { round-the-clock. }\end{array}$ & 1 & 2 & 3 & 4 & 5 \\
\hline
\end{tabular}




\begin{tabular}{|l|c|c|c|c|c|}
\hline $\begin{array}{l}\text { Engagement of e-payment: systems, } \\
\text { e-accounts/currencies. }\end{array}$ & 1 & 2 & 3 & 4 & 5 \\
\hline $\begin{array}{l}\text { Positioning and advertising of goods/services } \\
\text { exceptionally in the Internet. }\end{array}$ & 1 & 2 & 3 & 4 & 5 \\
\hline Other(please, write down) & 1 & 2 & 3 & 4 & 5 \\
\hline & & & & & \\
\hline
\end{tabular}

\section{PART III. CHANNELS OF DIGITAL SHADOW ECONOMY}

5. Please, evaluate the activity fields of digital shadow economy proposed below:

\begin{tabular}{|l|c|c|c|c|c|}
\hline \multicolumn{1}{|c|}{$\begin{array}{c}\text { ACTIVITY FIELDS of digital } \\
\text { shadow economy }\end{array}$} & $\begin{array}{c}\text { Strongly } \\
\text { disagree }\end{array}$ & Disagree & $\begin{array}{c}\text { Neither agree } \\
\text { or disagree }\end{array}$ & Agree & $\begin{array}{c}\text { Strongly } \\
\text { agree }\end{array}$ \\
\hline Online shops with e-payment systems. & 1 & 2 & 3 & 4 & 5 \\
\hline Poker/casino/bingo suppliers' portals. & 1 & 2 & 3 & 4 & 5 \\
\hline E-game portals. & 1 & 2 & 3 & 4 & 5 \\
\hline E-services, e.g. e-advert. & 1 & 2 & 3 & 4 & 5 \\
\hline Online broadcasts. & 1 & 2 & 3 & 4 & 5 \\
\hline E-trade in social networks. & 1 & 2 & 3 & 4 & 5 \\
\hline $\begin{array}{l}\text { Payments in bitcoins and other } \\
\text { cryptographic currencies. }\end{array}$ & 1 & 2 & 3 & 4 & 5 \\
\hline E-advert sites. & 1 & 2 & 3 & 4 & 5 \\
\hline Other (please, write down) & & & & & \\
\hline
\end{tabular}

PART IV. PERSONAL EXPERIENCE IN DIGITAL SPACE

6. Have you ever used services in e-space?
$\square$ Yes
No (please, go to question 9)

7. What services in e-space have you used? (please, write down) 


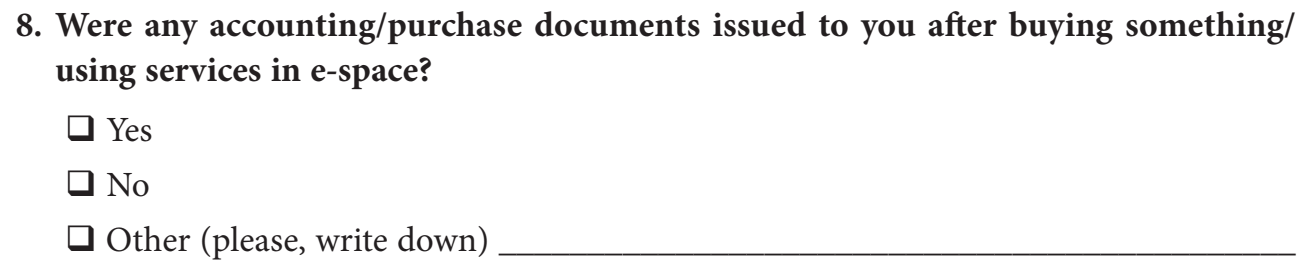

9. Please, give some suggestions on how to reduce the size of digital shadow economy:

\section{Thank you for your cooperation!}

Rita REMEIKIENĖ (Assoc. Prof. Dr) has accumulated much scientific experience in the research of self-employment and business environment conditions in transition economies. In 2012, she defended the doctoral thesis on the topic "The factors of self-employment in transition economies" (the field of economics, social sciences), which won Lithuanian Science Council's award for the best research in the field social sciences. During her scientific career, Rita Remeikienè has prepared and published over 40 scientific articles (6 of which were included in ISI basic list issues; 7 - in ISI database referred issues; 14 - in international databases referred issues, etc.). The main topics of the research are linked to the issues of expansion of opportunities in the labour market, shadow economy, outsourcing, gender gaps, and entrepreneurship. Previously, Rita Remeikienè participated in 3 chartered national projects and led the study project "Nord Plus Horizontals". At present, she is leading the scientific national (Lithuanian) project "Digital shadow economy".

Ligita GASPARÉNIENE் (Prof. Dr) links her research fields to the analysis of macroeconomic phenomenon's, practical decisions of outsourcing and estimation of shadow economy. In 2009, she defended the doctoral thesis on the topic "The impact on transaction costs on outsourcing contracts" (the field of economics, social sciences). During the period of 2005-2015, the researcher has published over 40 scientific articles and issued two monographs titled "The methodology of the estimation of external service transaction costs" and "Estimation of financial investment and investment projects". The basic fields of her scientific work include transaction costs, shadow economy, real estate economy. Ligita Gaspareniene participated in 3 chartered national projects and is currently involved in the scientific national (Lithuanian) project "Digital shadow economy" as the principal researcher.

Friedrich Georg SCHNEIDER (Prof. Dr) links his research fields to the analysis of general economic policy, public finance, shadow economy, organized crime, environmental economics, privatization and deregulation policies, public choice. He has a consulting experience (studies, projects) for Austrian industries, Federal Austrian Chamber of Commerce, Federal Austrian Ministry of Economics, Federal Austrian Ministry of Finance, National Central Bank of Germany, Austria, Bank Austria, Brussels EU Commission, World Bank. From 1974 until 2015 professor wrote 74 books, 215 articles in Scientific Journals, 187 Articles in Edited Volumes and Readers. 